\title{
THE PHILOSOPHY IN TIBB NABAWI
}

by A.H. Basalamah. M.D., F.A.C.S., F.R.C.O.G., Chairman and Head of Department of Obstetrics and Gynecology: Foundation Dean. Faculty of Medicine and Allied Sciences and University Hospital; King Abdul Azir University, Jeddah. Saudi Arabia

DOI: http://dx.doi.org/10.5915/14-1-12112

Tibb Nabawit may be described as the idea or philosophy that Mohammed $(\mathrm{PBC})^{2}$, the Prophet of Islam. propounded for the practice of traditional medicine. Greece. China. India, and Persia all had systems of traditional medicine. Each of these aimed at relieving pain and suffering of the sick to the best of extant knowledge. This knowledge was passed from generation to generation by these practitioners. But Tibb Nabawi as a practice of traditional medicine goes beyond the restriction, and propounds a philosphy which defines both disease and its cure as complementary, and encourages man to believe in Allah (Grod), as the omniscient Creator.

Muslims believe that Mohammed (PBUH) was the messsenger of Allah, and he said nothing and did nothing but what Allah wished him to say or willed him to do. Says one of the verses of Qur'an. the book of Islam:

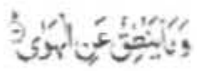

(Ma yantak en al hawa)

meaning, he, the Prophet, will not say anything out of air: i.e.. untruth. Thus, all that Mohammed (PBUH) said was dictated to him by the Almighty God.

In another phrase from the Quran, it is written:

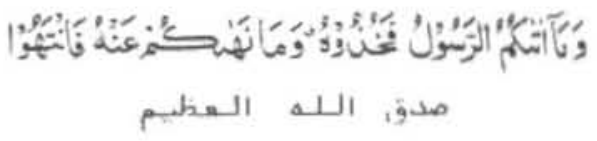

(Wama atakum al rasool fa khtoh: wama nahakum anh fa antho)

i.e., "what the Messenger, the Prophet has brought for you, take it. and what he asks you not to do you must not do it". So a philosophy of medicine brought by an author of that character must have a special role to play in human health and well-being.

There are many aspects of Tibb Nabawi which can be read or talked about, but I would like to present an aspect which shows how Tibb Nabawi is distinguishable from the other traditional medicines.

In a Haadith' about the healing of disease,

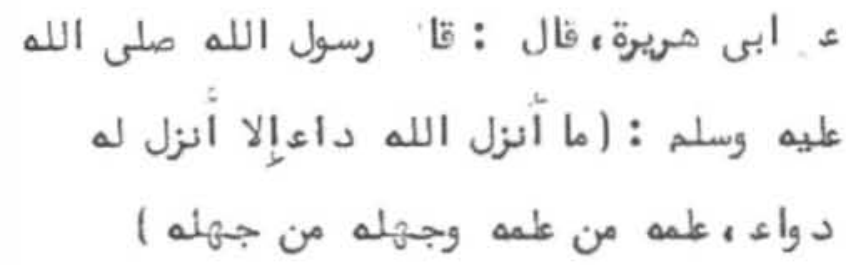

Abu Hurairah records that the Prophet (PBUH) said: "Allah (God) never creates a disease unless he creates a cure for it ....

Also, it was the Prophet (The Author) of Tibb Nabawi who said in a Haadith reported by Usama Ain Sheraik: "I was with the Prophet (PBUH) when some Arabs came to him and asked. "Prophet, do we take medicine for treatment?"*

He said, "Oh you servants of Allah, take medicine as Allah Almighty has not created a disease without having created a cure for it - except one illness".

$$
\begin{aligned}
& \text { من حديثأبن زياد عن أسأمه بن ثريك } \\
& \text { تال : كنت عد أنرسول صلى ألله عليه وسلم } \\
& \text { وجاء ت الأعرأبفالو : يا رسول الله } \\
& \text { أنتدأوت ؟ تال : لحم يا عاد ألنه تدأوا }
\end{aligned}
$$

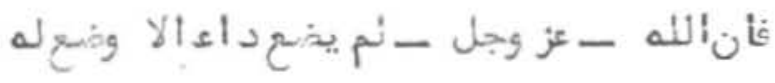

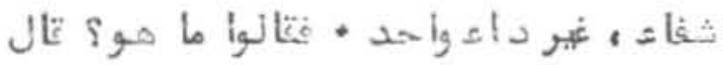

$$
\begin{aligned}
& \text { - }
\end{aligned}
$$

They asked. "What is it?"

He said. "Old Age".

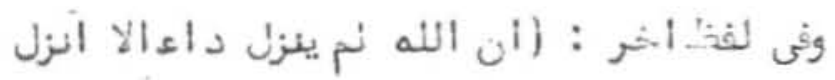

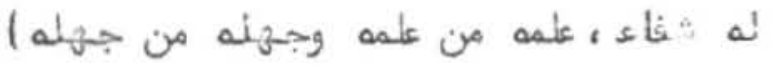

In another saying: "Allah (God) never creates a disease (or illness) without providing a cure, many people know about the disease and its cure and many are still ignorant". In other words, the Haadith is telling us. if there is illness or disease and suffering there is also treatment or cure for that illness on Earth.

If we look deeply and carefully at the Haadith mentioned above, we find it envelops many facts, but ones which are important and relevant to our topic in Tibb Nabawi are those that confirm and assure us of the presence of a cure and treatment of every disease and illness. It also clearly indicates that there is always a cause for a disease. For Muslims and true believing scientists. the fact in the statement cannot be questioned because it comes from the Prophet.

A review of the history of medicine over the last fifteen centuries bears testimony to what has been said 
in that Haadith. Many diseases and illnesses have been controlled by effective medicines and many causes have been discovered. thus helping in eradication of disease,

We as physicians. (according to our present knowledge). believe that there are still the so-called incurable diseases. But, in fact. such a term should not exist because a Haadith said:

Allah never creates a disease unless he makes a cure for it: many people know about the disease and its cure and many are still ignorant". So perhaps we are still ignorant.

So Tibb Nabawi offers a continual assurance to the (believer) scientist, that his efforts sooner or later are going to be fruitful. This provides hope for suffering humanity that there is a cure for every illness and for all diseases. Such facts, hopes, and assurances, if they had been given by any other author of traditional medicine. would be hard to accept, but we could readily accept the Prophetic words of Mohammed (PBUH).

The other aspect of Tibb Nabawi which is not stressed by the authors of traditional medicine is the pharmacological fact. In Tibb Nabawi it is stressed that it is not only the right medicine which will cure the discase. but the right medicine with the right dose.

In a Haadith reported by Joher Bin Abdullah:

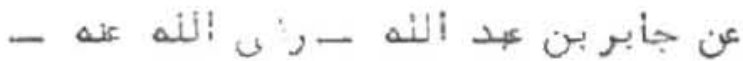

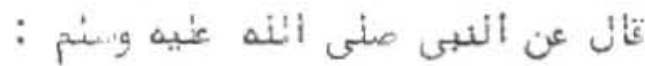

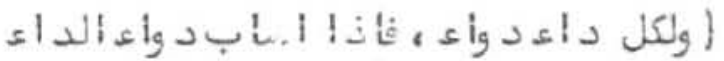

$$
\begin{aligned}
& \text { برأ بأذن إنله }
\end{aligned}
$$

the Prophet. Mohammed (PBUH) said: "For every disease there is a cure, when the cure (medicine) matches the disease, the person recovers. by the will of Allah". This sentence is even more true today and will remain so for the future.

Yet another aspect of Tibb Nabawi which I would like to mention. is the status and position of the physician or healer. If a person has his status ascribed by Allah (ALMIGHTY GOD), then this privilege will be incomparable. We read in Tibb Nabawi: that Prophet Ibrahim (PBUH) asked: "Oh God. who is the creator of the diseases?"

God (ALLAH) said, "I" (from me)

"Who is the creator of the cures?"

God said: "1" (from me)

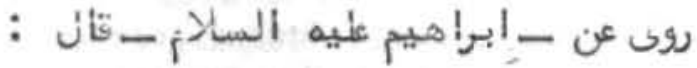

$$
\begin{aligned}
& \text { يارب ممن أنداء ؟ عال : منى ثال : ممن } \\
& \text { الدواء }
\end{aligned}
$$

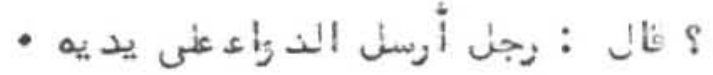

Ibrahim said. "Then what is the role of the physician?" ALMIGHTY GOD said, "He is a man; I send the cure through his hand".

So the physicians should look at themselves and their art in this spiritual light. and they should work and behave assuming that noble status. One can imagine then the benefits that would accrue and the excellent patient-physician relationship that would result.

\section{CONCLUSION}

In conclusion. Tibb Nabawi provides a philosphy and a direction as well as an indirect and invisible power to light the pathway providing a dedicated scientist. guidance and hope and enjoining him to try to discover a cause and to discover a cure.

These aspects of Tibb Nabawi were not inherent in other traditional medicines. They are great principles and should find a role in the science of medicine as they have done in the past, are doing in the present, and also will be doing in the future and all times to come.

\section{DEFINITIONS}

1. Tibb Nabawi: Medicine as advocated or practiced by Mohammed (P.B, U,H.).

2. P.B.U.H.: Prayer and blessings of All upon him.

3. Haadith: A saying of the Prophet as recorded by his companions.

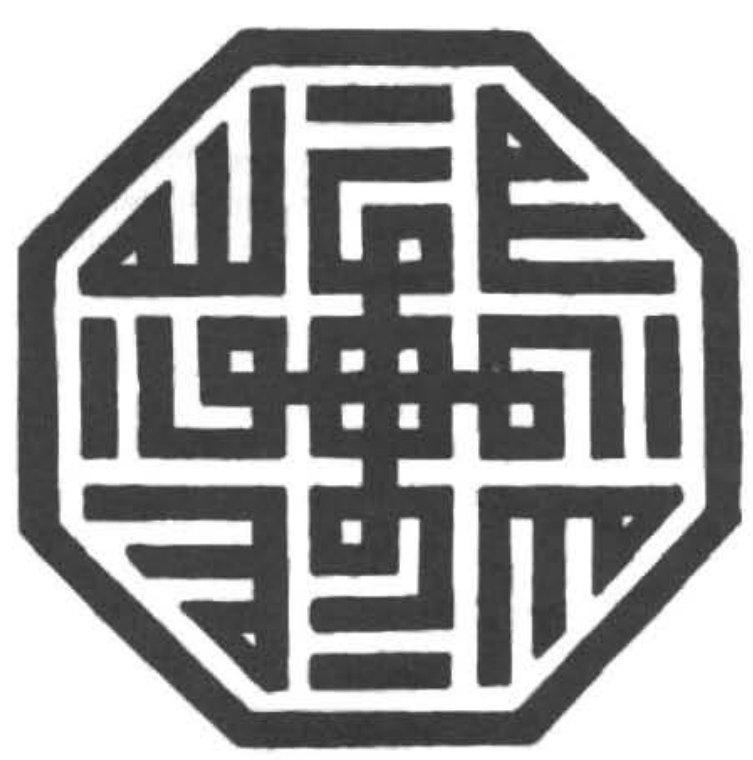

